Kacziba Péter ${ }^{1}$

\title{
Az amerikai és a brit diplomácia szerepe az 1974-es ciprusi konfliktusban
}

\section{The Role of American and British Diplomacy in the Cyprus Conflict of 1974}

\begin{abstract}
Absztrakt
A tanulmány az 1974-es ciprusi eseményekben betöltött amerikai és brit szerepvállalás jellegzetességeit vizsgálja. Az Amerikai Egyesült Államok kapcsán rámutat az amerikai hintapolitika jelentőségére, amely hallgatólagos hozzájárulásával a ciprusi puccs előtt Görögország terveit, a török beavatkozás után viszont már Ankara stratégiai elképzeléseit támogatta. A britek esetében a beavatkozási kényszer és a tényleges mozgástér közötti különbségeket emelem ki: bár London határozottan tiltakozott az 1960-as években kialakult status quo megváltoztatása ellen, gyakorlati mozgástere sem a Makáriosz elnök elleni puccs, sem az azt követö török intervenció megakadályozásában nem volt. A tanulmány szerint az amerikai és a brit szerepvállalás fajsúlyos szerepet játszott a Cipruson kialakult akut konfliktus egyik legfontosabb eseményének történetében, hiszen míg az Amerikai Egyesült Államok (a továbbiakban: Egyesült Államok, USA) közvetve vagy közvetlenül, de támogatta a regionális hatalmak nacionalista elképzeléseit, addig az érzékeny egyensúlyt megörizni kívánó Egyesült Királyságnak sem gyakorlati kapacitása, sem életképes megoldási javaslata nem volt a helyzet rendezésére.
\end{abstract}

Kulcsszavak: ciprusi konfliktus, görög-török ellentét, diplomáciatörténet, nemzetközi szerepvállalás

Pécsi Tudományegyetem Bölcsészettudományi Kar Politikatudományi és Nemzetközi Tanulmányok Tanszék, egyetemi adjunktus - University of Pécs, Faculty of Humanities, Department of Political Science and International Studies, assistant professor, e-mail: kacziba.peter@pte.hu, ORCID: https://orcid.org/0000-0002-9567-5363 


\begin{abstract}
The study examines the characteristics of American and British involvement in the 1974 events in Cyprus. Regarding the United States, it highlights the importance of Kissinger's controversial foreign policy which prior to the coup d'état supported the plans of Greece, while after the Turkish intervention, backed the strategic ideas of Ankara. In case of Britain, the study examines the difference between British goals of intervention and actual possibilities for manoeuvring: it emphasises that even though London strongly opposed the change of the status quo formed in the 1960s, its practical intervention was not able to prevent the coup against President Makarios or the subsequent Turkish intervention. The paper thus argues that the U.S. and British involvement played a major role in the events of 1974 in which the United States, directly or indirectly supported the nationalist ideas of regional powers, while the United Kingdom wishing to maintain the delicate balance in the island had neither capacity to avoid the catastrophe nor viable suggestions to solve the existing disputes.
\end{abstract}

Keywords: Cyprus conflict, Greek-Turkish conflict, diplomatic history, international context

\title{
Bevezetés
}

Ciprus azok közé az egykori brit gyarmati területek közé tartozik, amelyek a második világháború óriási anyagi megterhelésének eredményeként az 1960-as évek elejére lassan lemorzsolódtak a Brit Birodalomról. London visszavonulásával - Stella Soulioti kifejezésével élve - nemcsak „megbéklyózott függetlenséget” és etnikai ellentéteket, de egyben hatalmi ürt is hátrahagyott, amelyet a térség regionális hatalmai - Görögország és Törökország - igyekeztek minél hamarabb betölteni. ${ }^{2}$ Bár a sziget függetlenségének kikiáltása az első pár évben bizakodó és reményteljes jövőképet mutatott, a Görögország, Törökország és Nagy-Britannia által meghatározott alkotmány visszásságai már 1963-1964 fordulójára szembetűnővé váltak: ekkorra a török ciprióta alelnök vétói működésképtelenné tették, míg a görög ciprióta milíciák törökök elleni támadásai harctérré változtatták az országot. A török ciprióták enklávékba kényszerítésével, ${ }^{3}$ az ENSZ-csapatok bevonulásával, illetve a közösségek közötti intenzív tárgyalások megindításával a polgárháborús helyzetet 1964 nyarára valamelyest sikerült pacifikálni, a kérdés rendezésére

Soulioti, Stella: Fettered Independence: Cyprus, 1878-1964, Minnesota, Modern Greek Studies/University of Minnesota, 2006.

3 A török ciprióta enklávék közül a legnagyobb a Nicosia-St.Hilarion enklávé (másnéven Günyeli) volt, amely ÉszakNicosiától egészen a Pentadaktilosz-hegységig húzódott, közel 25 ezer török cipriótának menedéket nyújtva. Famaguszta, Lefka, Tziaos, Limaszol, Larnaka, Pafosz, Limnitisz, Kokkina és Louroutzina szintén rendelkezett török enklávéval, 1974-ig ezekben a szeparátumokban élt a mintegy 117 ezer fönyi török kisebbség döntő többsége. 
1963-ban ${ }^{4}$ és 1964-ben ${ }^{5}$ született terveket azonban vagy az egyik, vagy a másik fél ellenkezése miatt nem sikerült elfogadtatni. Ez továbbra is rendkívül instabil helyzetet eredményezett, és tulajdonképpen csak az amerikai diplomácia fellépésének köszönhető, hogy egy újabb konfliktus kapcsán, 1967-ben sikerült megállítani Ankara mozgósítását, amely Ciprust intervencióval, Görögországot pedig háborúval fenyegette. A következő éveket az 1967-ben hatalomra került görögországi junta ciprusi térnyerése jellemezte, amely végül 1974. július 15-én egy Athén által szervezett puccsba torkollott. Mivel a puccsot végrehajtó Ciprusi Nemzeti Gárda a demokratikus úton megválasztott III. Makáriosz elnök helyére egy szélsőségesen nacionalista bábkormányt ültetett, ezért Ankarában Bulent Ecevit miniszterelnök, a török Nemzetbiztonsági Tanács egyetértésével még ugyanaznap este elhatározta, hogy a helyzet rendezése érdekében akár katonai erővel is beavatkozik. Erre a szigetország alkotmányos kereteinek védelmét szolgáló háromhatalmi garanciaszerződés hatalmazta fel Ankarát, amely kimondta, hogy „[...] a három garantáló hatalom mindegyike fenntartja magának az önálló cselekvés jogát, azzal az egyedüli céllal, hogy visszaállítsa a jelen Egyezmény által létrehozott állapotokat". 6 Mivel mind a beavatkozásra készülő Ankara, mind a Ciprus annektálását fontolgató Athén elzárkózott a tárgyalásoktól, és július 18-án Harold Wilson brit miniszterelnök is visszautasította a törökök közös intervencióra vonatkozó ajánlatát, ezért Törökország július 20-án már a diplomáciai erőfeszítések kudarcára hivatkozva indíthatta meg támadását. ${ }^{7}$ A két hullámban lezajló intervenció/invázió ${ }^{8}$ azonban nem állította helyre a szigetország korábbi alkotmányos rendjét, sőt megszegte a garanciaszerződés 2. cikkelyében meghatározott pontokat, amelyek az okkupációt, uniót és a sziget területi integritásának megtörését kifejezetten tiltották. Bár a török beavatkozás két hulláma között lezajló első genfi konferencián többször felmerült annak igénye, hogy „a szigeten állomásozó csapatok és fegyverek számának szakaszos redukálása” csak „egy mindkét fél által elfogadott megegyezés esetén", tehát a ciprusi kérdés rendezését követően következzen be, mégis az okkupációt a nemzetközi közösség azóta is illegálisnak tekinti. ${ }^{9}$ A kérdés ezután magától értetődő: a döntésre képes nagyhatalmak - elsősorban az USA - és regionális hatalmak - Nagy-Britannia - miért nem akadályozták meg Törökország katonai akcióját? Milyen nemzetközi és belpolitikai folyamatok befolyásolták az amerikai és a brit diplomáciát a kérdéses időszakban, és ezek milyen hatással voltak a ciprusi eseményekre? A tanulmány ezekre a kérdésekre kíván röviden reflektálni.

4 Az Achenson-terv szerint Ciprus választhat az enoszisz (Görögországgal történő egyesítés) vagy a függetlenség között. Törökország cserébe katonai bázist létesíthet a Karpaz-félszigeten, amelyet a török állam oszthatatlan részévé nyilvánítanának. A fennmaradó, görögök által ellenőrzött országrészben három, területi autonómiával rendelkező kantont kapnának a török ciprióták, ahonnan a görög lakosságot kitelepítenék. A terv első változatát először mindkét anyaország elfogadta, később Görögország Makáriosz határozott követelésére elutasította azt.

5 A Galo Plaza-terv egy olyan uniót hozott volna létre, amelyben a törökök jogait ideiglenes kisebbségi intézményrendszer biztositotta volna, egy ENSZ-biztos felügyelete alatt. A törökök elutasították a tervet.

Kalmár Zoltán: Makáriosz alkotmányreformja és a ciprusi válság, Acta Scientiarum Socialium, 36 (2012) 95-102.

7 Türkmen, Füsun: Cyprus 1974 Revisited: Was it Humanitarian Intervention? Perceptions - Journal of International Affairs, $10(2005 / 4) 61-88$

8 Az 1974 július 20. és augusztus 17. között lezajló török beavatkozást a görögök invázióként, míg a törökök „boldog békehadműveletként", humanitárius intervencióként értékelik.

9 Asmussen, Jan: Cyprus at War. Diplomacy and Conflict during the 1974 Crisis, London, IBT Tauris, 2008, 168-169.; Drousiotis, Makarios: Cyprus 1974 - Greek coup and Turkish invasion, Bibliopolis, Möhnesee, 2006, 244-245. 


\section{Az Amerikai Egyesült Államok szerepe}

Washington közvetve már 1947-töl - a Truman-doktrína kihirdetése és a Görögország feletti patrónusi szerep brit-amerikai őrségváltása óta - az egyik legmeghatározóbb tényezője volt a Ciprust érintő nemzetközi döntéseknek. Fajsúlyos szerepe volt a szigetország függetlenségének kieszközlésében és kikiáltásában, hiszen az új állam létrehozásának diplomáciai támogatása mellett közvetve a CIA finanszírozta az EOKA ${ }^{10}$ elnevezésű szélsőségesen brit-, majd törökellenes paramilitáris szervezetet, azzal az egyértelmű szándékkal, hogy az összeomlóban lévő brit birodalom stratégiailag fontos gyarmatterülete ne az óriási ${ }^{11}$ tömegtámogatottsággal rendelkező kommunista AKEL ${ }^{12}$ párt, tehát tulajdonképpen Moszkva ölébe hulljon. ${ }^{13}$ Természetesen az amerikai szerepvállalás önmagában nem lett volna elegendő a sziget későbbi függetlenségének kikiáltásához, ugyanakkor a nagyhatalmi nyomás mind a britek, mind a regionális hatalmak, mind pedig a helyi közösségek számára fontos nyomásgyakorlási tényezőnek bizonyult.

A brit-amerikai örségváltás Ciprus esetében hivatalosan 1964 elején következett be, amikor Douglas Home brit miniszterelnök kijelentette, hogy Londonnak a továbbiakban nem áll módjában aktívan befolyásolni a szigeten zajló eseményeket: kizárólag a UNFICYP ${ }^{14}$ keretein belül, illetve diplomáciai eszközökkel tudja segíteni az USA- és a NATO-térségbeli érdekeit. ${ }^{15} \mathrm{~A}$ brit döntést nem pusztán a szigeten zajló etnikai villongások kezelhetetlensége, de egyben Törökország növekvő érdeklődése is indukálta, egyértelmű volt ugyanis, hogy a NATO második legerősebb hadseregével rendelkező Ankarát a csekély mértéküre redukálódott brit tekintély nem fogja eltántorítani egy esetleges ciprusi beavatkozástól. ${ }^{16} \mathrm{Az}$ USA megjelenésével az erőviszonyok megváltoztak, az erélyes hangvétel, valamint a térségben állomásozó 6. amerikai flotta pedig többször is elegendőnek bizonyult a török mozgósítás leállításához. A Washingtonból érkező "rendreutasítások" ugyanakkor korántsem tettek jót az amerikai-török kapcsolatoknak, sőt a szélsőségesen nacionalista athéni junta és az USA szinte baráti kapcsolata komolyan felvetette a török szövetség elvesztésének lehetőségét. A Görögországgal és Törökországgal egyaránt jó viszonyt ápolni igyekvő Henry Kissinger amerikai külügyminisztert emiatt rendkívül kellemetlen helyzetbe hozta az Athén által szervezett ciprusi puccs, amely már nemcsak a kétoldalú kapcsolatok megromlásával fenyegetett, de a NATO egységét is veszélyeztette. Mindez ráadásul egy olyan időpontban következett be, amikor a Nixon-kormány a Watergate-botrány miatt komoly belpolitikai problémákkal küzdött, és a hidegháborúban beállt átmeneti

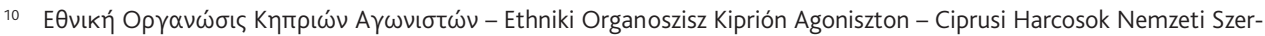
vezete.

11 Az AKEL népszerüségét jól jellemzi, hogy 1963-ban a szavazóbázis körülbelül 45\%-a volt a párt támogatója, ami az egyébként fragmentált pártrendszerben széles körü mozgásteret biztosított a kommunistáknak. James, Alan: Keeping the peace in the Cyprus of 1963-64, Palgrave Macmillan, New York, 2002, 44.

12 AvopӨ

13 Drousiotis (2006): i. m.

14 United Nations Peacekeeping Force in Cyprus - Egyesült Nemzetek Ciprusi Békefenntartó Erői.

15 Nicolet, Claude: United States Policy Towards Cyprus, 1954-1974: Removing the Greek-Turkish Bone of Contention, Mannheim und Möhnsee, Bibliopolis, 2001.

16 Ez egyébként tíz év múlva valóban bekövetkezik: Ankara 1974-es beavatkozását a britek figyelmeztetése ellenére is végrehajtotta. 
enyhülés nem tette lehetővé a nyílt amerikai beavatkozást egy elviekben „el nem kötelezett" állam belügyeibe. ${ }^{17}$

Utóbbi problémák figyelembevételével az 1974. július 15-én bekövetkező ciprusi puccs után a szigettel foglalkozó szakértők (Cyprus Desk Forces) öt lehetséges reakciót vázoltak fel Henry Kissinger külügyminiszter számára:

a) A görögországi junta újdonsült ciprusi bábjának, Nikosz Szampszon kormányának elismerése. Az amerikai külügy ebben a verzióban az amerikai-görög kapcsolatok jelentős javulásával, ugyanakkor a török szövetség elvesztésének lehetőségével, illetve erős nemzetközi kritikai reakcióval számolt.

b) Az új ciprusi rezsim kiközösítése, illetve Makáriosz elnöki pozíciójának hivatalos és nyílt támogatása. Az amerikai szakértők ebben az esetben a görög-amerikai kapcsolatok jelentös romlásával számoltak, továbbá a török katonai beavatkozás lehetőségét is feltételezték.

c) Görögország nyomás alá helyezése Makáriosz elnöki pozíciójának revideálása érdekében. Washington feltételezése szerint ez a verzió csak Athén elleni szankciók segítségével érne el eredményt, amely mélyrepülésbe lökné a görög-amerikai kapcsolatokat, de elejét venné a törökök beavatkozásának.

d) A görögországi junta visszavonulásra kényszerítése az USA, a Szovjetunió és Törökország együttes diplomáciai fellépésével. Ennek a verziónak a hátrányát a görög szövetség elvesztése, illetve a szovjetek ciprusi megjelenése jelentette.

e) Kivárás, a görög és a török szövetség fenntartására irányuló külpolitika alkalmazása. ${ }^{18}$

Kissinger utóbbiak közül a legutolsót választotta: az amerikai külügy a puccs és a török beavatkozás között eltelt időszakban hitet tett Ciprus függetlensége és területi integritása mellett, ugyanakkor hivatalosan nem ismerte el sem a junta által támogatott Szampszont, sem pedig a puccs által eltávolított Makárioszt. A kivárásra alapozott taktikát nagyban befolyásolta, hogy Kissinger kezdetben összeegyeztethetőnek vélte a görögországi junta és Washington terveit az egyre inkább Moszkva felé tekintő és a kommunista AKEL támogatását élvező Makáriosz eltávolítása érdekében. ${ }^{19}$ Mivel azonban a törökök elleni kegyetlenkedéseiröl hírhedt Szampszon Ankara számára elfogadhatatlan volt, ezért az amerikai külügyminiszter William B. Macomber ankarai amerikai nagykövet útján Bulent Ecevit török miniszterelnökkel is felvette a kapcsolatot, és érd ek lödött, hogy Törökország milyen feltételek mellett lenne hajlandó a fegyveres beavatkozás lehetőségét elvetni. ${ }^{20} \mathrm{~A}$ sokatmondó kérdés hangvétele azonban jelentősen eltért a korábbi évek amerikai hozzáállásától, és nem említette sem azt, hogy az USA elfogadhatatlannak tartaná a török beavatkozást, sem azt, hogy akár szankciókat is alkalmazva megakadályozná azt: az amerikai külügy ebben az időszakban már érzékelhetően megértéssel fogadta a törökök intervenciós szándékát. Erre Washingtonnak nemcsak a háromhatalmi garanciaszerződés pontjai miatt

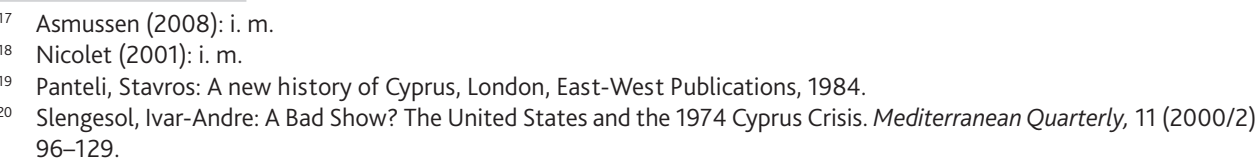


volt oka - amelyek tulajdonképpen feljogosították a törököket a beavatkozásra -, de egyúttal azért is, mert a görögök túlzott ciprusi térnyerésétől a NATO délkeleti szárnyának meggyengülését, legrosszabb esetben a török szövetség elvesztését várták. ${ }^{21}$

A kubai válság emlékével a háta mögött az USA tökéletesen megértette a török biztonsági aggályokat, egyúttal a török kisebbség védelmének biztosítását is szükségesnek tartotta. ${ }^{22}$ Ennek ellenére 1974. július 20 -a elött Washington politikáját a fegyveres beavatkozás elkerülése határozta meg, egy olyan diplomáciai megoldás kieszközlése, amely mind a görögöket, mind a törököket kielégíti, egyúttal a krízist a háromhatalmi szerződés országai és az USA hatáskörén belül tartja, távol az ENSZ-töl, ahol a szovjeteknek beavatkozási lehetőségük nyílhatna. A Szovjetunió térnyerésének lehetősége nem pusztán hidegháborús paranoia volt, a ciprusi események ugyanis Moszkva figyelmét is a NATO délkeleti szárnyától „kőhajításnyira” lévő szigetre irányították. Erre a legföbb bizonyíték, hogy a nicosiai orosz nagykövet még a puccs napján informálisan megkérdezte a ciprusi brit nagykövetet, hogy London "hogyan reagálna, ha a helyzet rendezésére szovjet csapatok érkeznének a szigetre". 23 Bár a felháborodott Kissinger hamar a washingtoni szovjet nagykövet tudomására hozta, hogy a nyugati diplomácia ezt a lehetőséget nem favorizálja, mindazonáltal Moszkva érdeklődése továbbra is megmaradt: a szovjet flotta néhány egysége július 19-én a Kirénia környéki vizekre érkezett, és a török invázió mindkét hulláma alatt a helyszínen maradva, „a Szovjetunió szemeként és füleként" viselkedve figyelte az eseményeket. ${ }^{24}$

Az 1974. július 20 -án meginduló török hadmüveletek szükségszerüen átalakították a válság menedzselésére vonatkozó amerikai elképzeléseket, amelyeket ezt követően elsősorban a görög-török háború elkerülésére vonatkozó igények befolyásoltak. Ebben az esetben azonban nem a törököket, hanem az azonnali mozgósítást elrendelő és hadüzenettel fenyegetőző görögországi juntát kellett meggyőzniük, amely feladat legalább annyira bizonyult komoly kihívásnak, mint korábban Ankara kontrollálása. Az amerikai beavatkozásra ugyanakkor végül nem volt szükség, a Törökország beavatkozásának hírére frakciókra bomló junta saját magát gáncsolta el, magával rántva Nikosz Szampszon pár napot megélt ciprusi rezsimjét is. Az új helyzetben Konsztantinosz Karamanlisz újonnan kinevezett görög miniszterelnök rögtön a párbeszéd szükségessége mellett foglalt állást, amit Washington kormányának hivatalos elismerésével jutalmazott. Az új görög kormány gyors beiktatása változtatott Moszkva álláspontján is, a Görög Kommunista Párt, a KKE tagjainak brutális elhallgattatása miatt a legkevésbé sem preferált junta bukása után jóval nagyobb megértéssel fogadta a szövetségeseket kereső Karamanlisz-kormányt. A Szovjetunió irányváltását kiválóan tükrözte, hogy amikor a genfi konferencia előtt - Szampszon bukása után ideiglenesen Ciprus elnökének kinevezett - Glafkosz Kleridesz szovjet beavatkozást kért, akkor azt Moszkva elutasította, pontosabban csak közös amerikai-szovjet intervenció esetén tartotta lehetségesnek. ${ }^{25}$

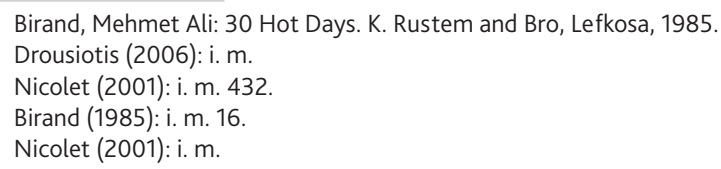


A ciprusi helyzet rendezésére 1974. július 25-én összehívott első genfi konferencia eredményeként a görög-török háborút ugyan sikerült elkerülni, Ciprus kérdésében azonban nem született érdemi elörelépés. A konferencia döntésképtelenségét nagyban befolyásolta, hogy ebben az időszakban az USA sem rendelkezett egységes irányvonallal a sziget jövőjét és a kialakult helyzet kezelését illetően. Míg Washingtonban a rendkívül befolyásos görög lobbi a török csapatok Ciprusról való „kiparancsolásáért” küzdött, addig az amerikai külügy két szakembere - Arthur Hartman és William Buffum - Cipruson és Genfben tájékozódott. ${ }^{26} \mathrm{~A}$ két szakértő tulajdonképpen ugyanazt a következtetést vonta le: míg Arthur Hartman kiemelte, hogy a ciprusi etnikai erőviszonyokat a török csapatok jelenléte tulajdonképpen kiegyenlítette, és hogy az egyensúly fenntartása érdekében a két fél szeparációja szükségszerü, addig William Buffum felhívta a figyelmet arra, hogy a genfi konferencia egyértelmüvé tette az 1960-ban létrehozott ciprusi állam működésképtelenségét, ráadásul a puccs és a török támadás után már felelőtlenség lenne a török csapatok kivonása és a két népcsoport újbóli „összeeresztése". ${ }^{27}$

Az 1974. augusztus 10-én összehívott második genfi konferencia alatt képviselt amerikai álláspont utóbbi véleményeket figyelembe véve egy, a sziget 30\%-át magában foglaló török kanton létrehozására törekedett, amely azonban ez esetben ellenkezett James Callaghan brit külügyminiszter álláspontjával, aki a törököket távol akarta tartani Ciprustól, és korántsem intervenciót, hanem a Brit Nemzetközösség egyik tagja elleni inváziót látott a törökök akciójában. ${ }^{28}$ Miután a konferencia az egyre növekvő török követelések miatt zátonyra futott, Ankara augusztus 14-én megindította második támadási hullámát, 17-ére pedig elfoglalta a sziget 36,2\%-át. ${ }^{29}$ Mivel az Amerikai Egyesült Államokban augusztus 9-én elnökváltás zajlott le és az új Gerald Ford-kormány regnálását magától értetődően nem egy megkérdőjelezhető katonai beavatkozással akarta elkezdeni, ezért az új helyzetben az amerikai diplomácia átmenetileg tulajdonképpen elismerte a török okkupációt, egyúttal a béketárgyalások és a ciprusi kérdés mielőbbi rendezése mellett foglalt állást. Ezzel ugyan megtartotta a törökök rokonszenvét, a másik oldalon azonban jelentősen rontott az amerikai-görög kapcsolatokon, aminek nemcsak Görögország NATO katonai szárnyából való kilépése lett az eredménye, hanem Roger Davies nicosiai amerikai nagykövet és egy munkatársának halála is, akiket a második török támadási hullám miatt felháborodott görög ciprióta tüntetők augusztus 19-én a nagykövetség előtti demonstráció során lőttek le (Güney, 2004). ${ }^{30}$ Bár ezek az epizódok csak időlegesen csökkentették az Egyesült Államok görögországi befolyását és jelenlétét, közvetett módon azonban hozzájárultak a görög társadalom számottevő részének máig érzékelhető Washingtonnal szembeni ellenérzéseihez. A görögök és görög ciprióták között egyaránt érzékelhető „Amerika-ellenesség” egyértelmű mellékterméke a kissingeri külpolitika világlátásának, amely nemcsak Ciprusra, de tulajdonképpen Görögországra is másodlagos hatalmi

26 Coufoudakis, Van: The Reverse Influence Phenomenon: The Impact of the Greek-American Lobby on the Foreign Policy of Greece, in: Cyprus and International Politics, Essays by Van Coufoudakis, Intercollege Press, Nicosia, 2006, 40-64.

Slengesol (2000). i. m.

8 Asmussen (2008): i. m

29 Coufoudakis (2006): i. m.

30 Güney, Aylin: The USA's Role in Mediating the Cyprus Conflict: A Story of Success or Failure? Security Dialogue, $35(2004 / 1) 27-42$ 
tényezőként tekintett, a hidegháborús versengés során pedig elsősorban valós regionális erővel rendelkező török igényekre fókuszált, veszélyt elsősorban a török-amerikai kapcsolatok megromlásában látott.

\section{Az Egyesült Királyság szerepe}

Az Egyesült Királyság szerepének vizsgálatakor három tényezőt kiemelten kell kezelnünk. Bár Londonnak a térségben betöltött korábbi befolyása 1974-re jelentősen redukálódott, a gyarmati múlt és történelmi kötelékek, a szigeten található brit bázisterületek és csapatok, illetve a garanciaszerződés nemzetközi jogi vonatkozásai még ebben az időszakban is széles körü mozgásteret biztosítottak az Egyesült Királyság számára. Utóbbi tényező́k természetesen a briteket is involválták a szigettel kapcsolatos belföldi és nemzetközi eseményekbe, egyúttal a törököket is arra sarkallták, hogy a Ciprussal kapcsolatos külpolitikai döntéseiknél a brit érdekeket figyelembe vegyék. Erre utal, hogy Törökország az 1974. július 15-én lezajló Makáriosz elleni puccs után a britekkel aktív tárgyalásokba bocsátkozott, az eseményekkel kapcsolatos egyeztetésen túl pedig egy közös intervencióra is próbálta Londont rávenni. A közös fellépésre a garanciaszerződés is lehetőséget biztosított, ennek birtokában tulajdonképpen az Egyesült Királyság lett volna az egyetlen olyan nyugati NATO-tagállam, amely jogosan és többé-kevésbé semlegesen léphetett volna fel Ciprus alkotmányos rendjének helyreállítása érdekében. A brit beavatkozás szintén lehetőséget biztosíthatott a törökök kontrollálására: egy közös fellépés esetén Ankara vélhetően jobban ragaszkodott volna a szigettel kapcsolatos nemzetközi egyezmények betartásához, amelyek ugyan lehetővé tették a garantáló hatalmak beavatkozását, ugyanakkor ezt az alkotmányos rend helyreállítására korlátozták. A britek ennek ellenére a közös intervenció lehetőségét határozottan visszautasították, a diplomáciai megoldás szorgalmazásán és a két fél közötti közvetítésen túl a válságban betöltött szerepüket minimálisra próbálták redukálni. Az Egyesült Királyság limitált szerepvállalását hivatalosan a Cipruson állomásozó brit katonai kontingens létszámával indokolta, London álláspontja szerint a szigeten jelen lévő brit erők az aktív beavatkozást nem tették volna lehetővé. ${ }^{31}$

London reakcióinak vizsgálatakor megállapítható, hogy a szigeten állomásozó brit csapatok létszáma a puccs időpontjában valóban nem volt magas: a szuverén bázisterületeken mintegy 3000 brit katona tartózkodott, ezt a létszámot növelték július 26-ára 5553-ra. Ez a szintén a térségben állomásozó HMS Hermes, HMS Devonshire és HMS Andromeda hadihajókkal, valamint az Akrotiri légibázis 12 Phantom vadászgépével sem jelentett ütőképes haderőt. ${ }^{32} \mathrm{~A}$ brit katonai részvételt azonban nem egyoldalú beavatkozás lehetőségeként, hanem a török haderővel együttesen fellépő seregrészként kell értékelnünk, amely viszont már több mint elegendö lett volna Szampszon eltávolítására és a rend helyreállítására. A britek azonban ennek ellenére

\footnotetext{
Kyrris, Costas P.: History of Cyprus, Lampousa Publications, Nicosia, 1996.; Birand (1985): i. m.; Panteli (1984): i. m.

32 Asmussen (2008): i. m.; Kazamias, George: From Pragmatism to Idealism to Failure: Britain in the Cyprus crisis of 1974, Hellenic Observatory Papers on Greece and Southeast Europe, (2010/42) 24-25.
} 
határozottan elutasították az intervencióban való részvételt, amelyet több egymástól különálló ok és/vagy lehetséges fejlemény eredményezhetett:

a) Harold Wilson miniszterelnök és James Callaghan külügyminiszter az 1960as évek végétől a britekkel szemben barátilag fellépő ciprusiakat - legyenek azok görög vagy török ciprióták -nem szerették volna bármely oldal támogatásával magukra haragítani. Erre nemcsak az 1950-es évek számos britek ellen elkövetett EOKA-merényleteinek keserü emléke figyelmeztette őket, de egyúttal Észak-Írország és az IRA példája is, amelyek tapasztalatait ismerve a ciprusi szuverén bázisterületeiket korántsem sem szerették volna ostromlott erődként viszontlátni. ${ }^{33}$

b) Szintén a távolmaradás mellett szólt, hogy egy esetleges részvétellel elveszíthették volna amúgy is vitatható semleges ciprusi státuszukat és ezzel a ciprusi békefenntartói misszióban (UNFICYP) betöltött pozíciójukat, ahonnan az ENSZ Biztonsági Tanácsa - érintettségre hivatkozva - már távol tartotta a töröket és a görögöket.

c) Beavatkozás esetén Nagy-Britannia szembe került volna az intervenciót határozottan elutasító Görögországgal, amely egyrészt még inkább aláásta volna a NATO egységét, másrészt súlyos következményekkel járhatott volna a nyilvánvaló görög-török háborús készülődés fényében. London tehát - Washingtonnal egyetértésben - ellenezte Görögország teljes elszigetelését, amely a szovjet befolyás térségbeli növekedését eredményezhette volna.

d) Az USA puccsban való érintettségét, ahogyan Ankara, úgy London is lehetségesnek tartotta. A feltételezést alátámasztani látszott Henry Kissinger július 15-e utáni magatartása, aki az ENSZ Biztonsági Tanácsában többször is a Szampszon-kormány és Makáriosz közötti párbeszéd szükségességéről, voltaképpen tehát a görög junta által támogatott új ciprusi rezsim elismeréséröl próbált egyezkedni. A britek a szuezi „fiaskó" után korántsem voltak hajlandóak az USA támogatása, de legalábbis taktikai beleegyezése nélkül beavatkozni Cipruson. ${ }^{34}$

Utóbbi érvek távol tartották Londont a törökökkel közös beavatkozástól, egyúttal a brit érdekeket a puccs előtti állapotok visszaállításának támogatásában jelölték ki. Bár involválódását London minimalizálni próbálta, szuverén bázisterületei és nemzetközi jogi kötelezettségei miatt az 1974. július 15-ei puccsot követően több fontos fejleményben is aktív szerepet játszott. Ezek közül az első a britek által évtizedekkel ezelőtt még élesen bírált Makáriosz közvetett támogatása volt: Ciprus legitim elnökét a puccs után rövid tróodoszi és páfoszi tartózkodás után brit közreműködéssel evakuálták Máltára, ahonnan Londonba szállították. Ez a segítség ugyan kezdetben nem jelentette Makáriosz elnöki pozícióinak visszaállítását, a puccs utáni tisztogatásoktól azonban megkímélte az elnököt.

33 Byrne, Sean J.: The Roles of External Ethnoguarantors and Primary Mediators in Cyprus and Northern Ireland, Conflict Resolution Quarterly, 24 (2006/2) 149-172.

34 Panteli (1984): i. m. 
Az Egyesült Királyság szintén fajsúlyos szerepet játszott a válság megoldására irányuló diplomáciai erőfeszítésekben. Ennek egyik platformja az ENSZ Biztonsági Tanácsa volt, amelynek határozatait a britek tulajdonképpen érintett félként tudták befolyásolni. A török beavatkozás első napján elfogadott, 353-as számú BT határozat ennek megfelelően tükrözi a brit érdekeket: a dokumentum felszólította a konfliktusban részt vevő feleket Ciprus szuverenitásának és területi integritásának tiszteletben tartására; az azonnali tűzszünet elfogadására; a szigeten állomásozó vagy a nap folyamán partraszálló külföldi (tehát a török mellett a görögországi) csapatok kivonására; a háromoldalú tárgyalások mielőbbi megkezdésére; illetve a szigeten állomásozó békefenntartókkal való együttműködésre..$^{35}$

London az ENSZ mellett szintén aktív szereplője volt a török beavatkozás két hulláma között lezajló genfi béketárgyalásoknak. A július 25. és 30 . között rendezett első genfi békekonferencián a britek kezdetben a görög és török álláspont között lavíroztak. A görögök szempontjából kedvező volt, hogy a britek is kifogásolták a török intervenciót, és jogi formulát próbáltak keresni a beavatkozás illegalitásának alátámasztására. Ezt a görög és a brit diplomácia a beavatkozás előtt elmaradó háromhatalmi konzultációban vélte felfedezni: London és Athén álláspontja szerint a július 20-án induló török intervenció jogszerütlen volt, mivel a kezdetekor még nem zárultak le a válság rendezését szolgáló és brit közvetítéssel zajló diplomáciai erőfeszítések. Míg jogi ügyekben a britek a görögök pártján álltak, addig a válságot előidéző okok tekintetében figyelembe vették a török álláspontot és a megváltozott realitásokat is. Ennek megfelelően a tárgyalások szakaszát lezáró közös deklaráció kilátásba helyezte a török ciprióták ENSZ által biztosított védelmét és új ciprusi alkotmány kidolgozását. Utóbbiaknál viszont hangsúlyosabb, hogy a deklaráció nem említette a török csapatok kivonását, csak az általuk addig elfoglalt területek növelésére vonatkozó tilalmat.

Míg az első genfi konferencia alkalmával a nemzetközi közösség jobbára megértéssel fogadta a török beavatkozást, addig a második konferencia idejére inkább a juntát felváltó és július 24-én hivatalba lépő Karamanlisz-kormány követelései váltak elfogadottá. A török kormány érzékelve a nemzetközi közösség szimpátiáaának változásait rövidre zárta a második békekonferenciát: a görög és görög ciprióta féltől a ciprusi állam föderális átalakítását, illetve lakosságcserét követeltek. A török kérés kapcsán ismét rendkívül hangsúlyossá vált a brit szerepvállalás, hiszen míg Kissinger arra próbálta rávenni a görögöket, hogy fogadják el a török javaslatot, addig Callaghan brit külügyminiszter kivárást javasolt a görög ciprióta delegációt vezetö Glafkosz Kleridesznek. Bár Kleridesz visszaemlékezéseiben elfogadhatatlannak minősítette a török követeléseket és eleve kizárta annak elfogadását, a brit tanács nyilvánvalóan fontos ütőkártyát jelentett az amerikai nyomásgyakorlással szemben. ${ }^{36} \mathrm{~A}$ továbbiakban ennek megfelelően a görög ciprióta delegáció a török követelések megvitatására 36-48 órás haladékot kért, amelyet Turan Güneş török külügyminiszter taktikai időhúzásnak minősített - Kleridesz későbbi visszaemlékezései szerint egyébként az is volt - és elhagyta a konferenciát. ${ }^{37}$

35 Tofallis, Kypros: A History of Cyprus. London, The Greek Institute, 2002.

36 O'Malley, Brendan - Craig, Ian: The Cyprus Conspiracy: America, Espionage and the Turkish Invasion, I. B. Tauris, London - New York, 2001.

37 O'Malley-Craig (2001): i. m. 
Ahogyan korábban is kiemeltem, az augusztus 14-én hajnalban zátonyra futó tárgyalásokkal egyidőben a török hadsereg ismételt támadást intézett a sziget ellen, és az augusztus 16 -ai tüzszünetig annak $36,2 \%$-át elfoglalta. Az intervenció második hullámának egyik alapvető mozgatórugója a brit és az amerikai hozzáállás közötti eltérés volt. Míg Callaghan még a genfi konferencián figyelmeztette a törököket, hogy egy újabb támadási hullám a garanciaszerződés biztos megsértését jelentené, addig Kissinger a görög junta által levezényelt puccs után szükségesnek tartotta a török ciprióta kisebbség védelmét, és támogatta Ankara erre vonatkozó területi elképzeléseit. Washington hallgatólagos támogatásával a háta mögött Törökország lényegében zöld utat kapott ciprusi inváziójához, amelyet ugyanakkor hadászati és politikai érvek miatt szándékosan limitált, kizárólag a sziget körülbelül harmadára korlátozva az okkupáció területi kiterjedését.

\section{Konklúzió}

Összefoglalásként megállapíthatjuk, hogy Törökország 1974-es ciprusi beavatkozása kizárólag azért következhetett be, mert a kérdéses időszakban a nemzetközi helyzet erre lehetőséget biztosított. Kissinger kezdeti kivárásra alapozott taktikáját, egyúttal először a görögöknek, később a törököknek kedvező „hintapolitikáját” az USA belpolitikai gyengesége, a szovjetek ciprusi megjelenésétől való félelme, egyúttal a NATO egységének fenntartására való törekvése eredményezte. Az amerikai külügyminiszter kezdetben a balra „húzó” Makáriosz eltávolítása érdekében összeegyeztethetőnek vélte Athén és Washington céljait, mivel tartott attól, hogy az érsek vezetése alatt Ciprus könnyen a Földközi-tenger „Kubájává" válhat. ${ }^{38}$ Később, az intervenció utáni reakciókat, valamint Ankara és Athén elszánt háborús készülődését látva, - a kisebbik rosszat választva - inkább szemet hunyt Törökország katonai beavatkozása felett, minthogy kockáztassa a NATO két tagországa közötti fegyveres konfliktus kirobbanását.

Míg Washington kétségbeesetten próbálta fenntartani a NATO egységét, valamint Törökország, Görögország és az USA elvileg baráti kapcsolatát, addig a Szovjetunió megelégedéssel fogadta az Észak-Atlanti Szövetségen belüli konfrontációt. Kezdetben diplomáciai támogatásáról biztosította Törökországot, majd a junta bukása után, az első genfi konferencia után magát kisemmizve érző Görögországot is. A szovjetek azonban diplomáciai próbálkozásaik ellenére távol maradtak az elsősorban a nyugati szövetségesek érdekkörébe tartozó ciprusi eseményektől, és továbbra is tartották magukat a be nem avatkozás elvéhez. Az Egyesült Királyság szerepe elsősorban a háromhatalmi garanciaszerződés és a szigeten található bázisterületek miatt volt kiemelkedő, amelyek révén Londonnak lehetősége adódott volna az események befolyásolására. A britek azonban igyekeztek minél kevésbé involválódni, amelyet egyrészt ciprusi semleges státuszuk fenntartása, másrészt külpolitikai gyengeségük indukált. Komplex diplomáciai szerepvállalásuk nézőponttól és megítéléstől függően változik. Egyes vélemények szerint a görög cipriótáknak nyújtott brit támogatás okozta a görög ciprióták politikai ellenállását, amely nélkül a török invázió és a nyillt konfrontáció is

38 Panteli (1984): i. m. 
elkerülhető lett volna. Más vélemények szerint erélyesebb brit fellépésre lett volna szükség, amely révén Londonnak lehetősége lett volna a török agressziót megakadályozni. Utóbbi vélemények valóságtartalmának értékelése nélkül megállapítható, hogy a britek szerepvállalását a gyarmati berögződések, valamint a tényleges politikai és hadászati lehetőségek közötti komoly ellentmondások definiálták.

Végezetül érdemes röviden kiemelni, hogy a brit és az amerikai szerepvállalás az 1974 utáni időszakot is jelentősen befolyásolta. A ciprusi konfliktus rendezetlensége nem pusztán a béketárgyalásokban közvetlenül érdekelt felek kompromisszumképtelenségének eredménye, de a konfliktus rendezését elősegítő külső szereplők passzivitásának következménye is. Noha többször felmerült, hogy a britek a bázisterületeik átengedésével lendítik elöre a béketárgyalásokat, a retorikai szólamok hangoztatásán túl London sosem jutott el a gyakorlati megvalósításig. Ahogyan a britek, úgy a nagyobb mozgástérrel rendelkező amerikaiak sem kívánták regionális érdekeiket Ciprus „kedvéért” feláldozni, egyébként fajsúlyosnak tekinthető politikai, gazdasági vagy katonai nyomásgyakorlási lehetőségeiket pedig a béketárgyalások évtizedei alatt tulajdonképpen egyszer sem hasznosították. Bár ennek a nyomásgyakorlásnak hiányát a sziget mindkét oldalán gyakran sérelmezik és hiányolják, az 1995-ös daytoni békemegállapodás, illetve az annak eredményeként létrejött Bosznia-Hercegovina tökéletes bizonyítéka annak, hogy egy külső nyomásra létrehozott politikai egyezmény még nem feltétlenül eredményez jól működő államszervezetet vagy tényleges megbékélést. Jelenleg úgy tủnik, hogy a Ciprus kérdésében közvetlen befolyással rendelkező külső szereplők - köztük az Egyesült Királyság és az USA - ezeket a lehetséges veszélyeket felismerték és egy bizonytalan kimenetelü politikai megoldásért cserébe nem kívánják feláldozni a relatív stabilitást biztosító status quo-t.

\section{Felhasznált irodalom}

Asmussen, Jan: Cyprus at War. Diplomacy and Conflict during the 1974 Crisis, London, IBT Tauris, 2008.

Birand, Mehmet Ali: 30 Hot Days. K. Rustem and Bro., Lefkosa, 1985.

Byrne, Sean J.: The Roles of External Ethnoguarantors and Primary Mediators in Cyprus and Northern Ireland, Conflict Resolution Quarterly, 24 (2006/2) 149-172. DOI: https://doi.org/10.1002/crq.164

Coufoudakis, Van: The Reverse Influence Phenomenon: The Impact of the GreekAmerican Lobby on the Foreign Policy of Greece, in: Cyprus and International Politics, Essays by Van Coufoudakis, Nicosia, Intercollege Press, 2006, 40-64.

Drousiotis, Makarios: Cyprus 1974 - Greek coup and Turkish invasion, Bibliopolis, Möhnesee, 2006.

Güney, Aylin: The USA's Role in Mediating the Cyprus Conflict: A Story of Success or Failure? Security Dialogue, 35 (2004/1) 27-42. DOI: https://doi. org/10.1177/0967010604042534

James, Alan: Keeping the peace in the Cyprus of 1963-64, Palgrave Macmillan, New York, 2002. DOI: https://doi.org/10.1057/9781403900890 
Kalmár Zoltán: Makáriosz alkotmányreformja és a ciprusi válság, Acta Scientiarum Socialium, 36 (2012) 95-102.

Kazamias, George: From Pragmatism to Idealism to Failure: Britain in the Cyprus crisis of 1974, Hellenic Observatory Papers on Greece and Southeast Europe, (2010/42) 24-25.

Kyrris, Costas P.: History of Cyprus. Lampousa Publications, Nicosia, 1996.

Nicolet, Claude: United States Policy Towards Cyprus, 1954-1974: Removing the Greek-Turkish Bone of Contention, Mannheim und Möhnsee, Bibliopolis, 2001.

O'Malley, Brendan - Craig, Ian: The Cyprus Conspiracy: America, Espionage and the Turkish Invasion, I. B. Tauris, London - New York, 2001.

Panteli, Stavros: A new history of Cyprus, East-West Publications, London, 1984.

Slengesol, Ivar-Andre: A Bad Show? The United States and the 1974 Cyprus Crisis, Mediterranean Quarterly, 11 (2000/2) 96-129. DOI: https://doi. org/10.1215/10474552-11-2-96

Soulioti, Stella: Fettered Independence: Cyprus, 1878-1964, Minnesota, Modern Greek Studies/University of Minnesota, 2006.

Tofallis, Kypros: A History of Cyprus, The Greek Institute, London, 2002.

Türkmen, Füsun: Cyprus 1974 Revisited: Was it Humanitarian Intervention? Perceptions - Journal of International Affairs, 10 (2005/4) 61-88. 